\title{
Bir Tutundurma Aracı Olarak Reklamın Sosyal Medyada Uygulamalarına Yönelik Bir Araştırma: Instagram Örneği*
}

Öz

Pazarlama iletişimcileri için uygulamalarını gerçekleştirebilecekleri medya kanallar iletişim teknolojilerindeki gelişmenin sonucu olarak her geçen gün daha da artmaktadır. Ancak bu ilerlemeler aynı zamanda işletmelerin ve pazarlamacıların işlerini daha da zorlaş̧ırmaktadır. Çünkü bu teknolojik yükseliş beraberinde rekabeti daha kuzgin hale getirmektedir. Sosyal ağlar işletmelerin pazarlama faaliyetlerini gerçekleştirebilecekleri yeni bir pazarlama iletişimi unsuru olarak her geçen gün daha dikkat çekici hale gelmektedir. Bu çalışmayla da sosyal ağlardaki reklam uygulamalarının ağ üyeleri için ne kadar dikkat çekici olduğu görülmeye çalışılmıştır. Araştırmaya örnek sosyal ă̆ olarak Instagram seçilmiş ve Instagram kullanıcılarına yönelik araştırmanın anketi gerçekleştirilmiştir. Araştırma soruları bir link oluşturularak Instagram kullanıcılarına gönderilmiştir. Elde edilen bulgular içerisinde markalara ait reklamların daha dikkat çekici olduğu, reklamlarının daha akılda kalıcı olduğu ve reklamların kullanıcılar tarafindan sayfalarında paylaşılması kullanıcıları o ürünü satın almaya itmekte olduğu sonuçlarına varılmuştır.

Anahtar Kelimeler: Sosyal medya, Pazarlama, Reklam

Jel Sinıflaması: M31, M19, M37

\section{A Research on Advertising Applications in The Social Media as A Promotion Tool: Instagram Sample}

\begin{abstract}
The media channels through their applications can be implemented for marketing communications are increasing day by day as a result of the development in communication technologies. However, these developments also make the work of firms and marketers more difficult. Because of this technological rising, it makes competition fiercer. Social networks are becoming more and more attractive every day as a new marketing communication element in which businesses can conduct their marketing activities. In this paper, we tried to see how attractive the social applications are for the network members. Instagram was selected as a sample social network for research and a survey of the researcher for Instagram users was carried out. The research questions were sent to Instagram users by creating a link. Within the findings, it has come to the conclusion that branded ads are more striking, that their ads are more memorable, and that if they are shared by users, other users are motivating to buy that product.
\end{abstract}

Keywords: Social media, Marketing, Advertising,

Jel Codes: M31, M19, M37

\footnotetext{
*2. Uluslararası El Ruha Kongresinde Sunulmuş Olan "Sosyal Medyada Pazarlama Uygulamalarına Yönelik Bir Araştırma: Instagram Örneğì” adlı sözlü sunumun genişletilmiş halidir.

${ }^{1}$ Dr. Öğr. Üyesi, Bayburt Üniversitesi, Uygulamalı Bilimler Yüksekokulu, boragoktas@bayburt.edu.tr ORCID: https://orcid.org/0000-0003-2159-0241

${ }^{2}$ Öğr. Gör. Gazi Üniversitesi, Polatlı Sosyal Bilimler MYO, incierdogan@gazi.edu.tr

ORCID: https://orcid.org/0000-0003-2159-0241
} 


\section{Giriş}

İşletmeler hedef kitlesiyle daha etkili bir iletişim kurmak için farklı iletişim ortamlarını kullanarak mesajlar göndermektedir. Gelişen teknoloji sonucunda mali olanakları olduğunda işletmeler arasında büyüklük farklı da olsa kalite bakımından büyük fark ortaya çıkarmayacak ürünler ortaya konulmasına olanak sağlandığından rekabet ortamı daha da kızgın hale gelmiştir. Teknolojide yaşanan gelişmeye paralel olarak iletişim teknolojisinde de büyük gelişmeler yaşanmaktadır. Artık iletişim ortamları değişmekte, iletişim için geleneksel yöntemlerin önüne yeni iletişim kanalları geçmektedir. Teknoloji ilerledikçe iletişim kanalları da değişikliğe uğramaya devam etmektedir. İlerleyen iletişim teknolojisinin yarattığı yeni kanalları arasında Facebook, Instagram, Twitter gibi sosyal ağlar yer almaktadır ve artık iletişim yüz yüze tekniklerden adları sayılan bu çevrimiçi iletişim ortamlarına yerini bırakmaya başlamıştır.

Sosyal ağ kavramı gün geçtikçe önem kazanmakta ve yavaş yavaş önemli bir Pazarlama İletişimi unsuru olmaktadır. Sosyal medya, internet ortamında üretilen bilgilerin kullanıcılar arasında paylaşıldı ğı çift yönlü bir iletişim ortamıdır (Göktaş, 2017: 84). Günümüzde insanların çoğunluğu vakitlerini sosyal medya ağlarında geçirmektedir. Facebook, Twitter, Youtube, Instagram ve Myspace gibi sosyal paylaşım siteleri iletişimi "sanal” ortama taşımıştır. Sosyal paylaşımın en önemli özelliği içeriğin kullanıcı tarafından oluşturulması ve anlık paylaşıma olanak vermesidir (Ersöz, 2016: 304). Bununla birlikte sosyal medyadaki hızlı yeniliklerden dolayı çevrimiçi ortamları kullanmak bazı zorluklara da sahiptir. Çoğu işletme yöneticileri, sosyal medyaya yatırım yapmanın, satışları arttırıp arttırmayacağı, değerli müşterilerin keşfedilmesini sağlayıp sağlamayacağına ilişkin olarak sosyal medyanın gücünden şüphe etmeye devam etmektedirler (Wang, Hsiao, Yang ve Hajli, 2016: 56).

Reklamla geniş hedef kitleye mal ya da hizmet duyurulmaktadır. Reklam için bir ürünün parası ödenerek çeşitli mecraların kullanılmasıyla müşterilere duyurulması ve ürüne karşı tutumların olumlu yönde değişmesini sağlayarak bu tutumları davranışa dönüştürmek planlanmaktadır. Reklamı, üretici ile tüketici arasındaki bir bilgi ulaştırma aracı, bir iletişim aracı olarak görmek gerekir. Oluşturulan mesajların doğru kanal ve doğru zamanda uygun bir şekilde kodlanarak müşteriye iletilmesiyle marka ve müşteri arasında istenen ilişki oluşabilecektir.

İşletmelerce yoğun bir şekilde kullanılan bu reklam türünün tüketiciler tarafından da bu derece benimsenip benimsenmediği ne yazık ki sorgulanmamakta, sorgulansa bile göz ardı edilmektedir (Gürdin, 2017: 3). Sosyal ağların bu denli yaygın olarak kullanıldığı bir ortamda bu sosyal ağların pazarlama aracı olarak kullanılması da kaçınılmaz bir durum haline gelmiştir. Dolayısıyla pazarlama uzmanları da malları, hizmetleri, markalarıyla ilgili reklam çalışmalarını bu mecralarda da gerçekleştirmektedir. Peki bu sosyal ağlarda yer alan reklamlar profil sahipleri tarafından ne ölçüde dikkat çekmekte, onların bu ürün ve marklara karşı ilgi duymalarını sağlamakta, onları satın almaya itmektedir?

Sosyal ağlarda yer alan reklamların bu ağ kullanıcıları tarafından ne kadar dikkat çektiğinin ortaya konulabilmesi için gerçekleştirilen bu araştırmada öncelikle sosyal ağ ve reklam kavramları hakkında bilgiler verilmiştir. Kavramlara ilişkin aktarılan bilgilerin ardından sosyal ağ kullanıcıların ilgisinin anlaşılabilmesi amacıyla gerçekleştirilen anket çalışmasının bulguları sunulmuştur ve ardından da çalışmaya ait bir çıkarım yapılmıştır.

\section{Sosyal Medya}

Sosyal medya, çok önemli olmaya başladığından ve tüm dünyada çığ gibi büyüdügünden, daha karmaşık bir hal almaya başlamıştır. Sosyal medyanın artan ününden dolayı örgütler, sosyal 
medyanın nasıl kullanılacağı ve nasıl yönetilmesi gerektiğine büyük önem vermeye başlamıştır (Di Satso vd., 2011: 325).

Sosyal medya, alanyazında çeşitli şekillerde tanımlanmıştır, ancak en çok: "çevrimiçi sosyal etkileşimler ve platformlar yoluyla bilgi üretimi, tüketimi ve değiş tokuşu" şeklinde vurgulanmaktadır. Pratikte, sosyal medya, konuların tartış1labileceği forumlar, bloglar, belirli bir konuda daha fazla bilgiye sahip wikiler, sosyal ağlar ve çoklu ortam siteleri gibi insanların iletişim kurduğu belirli platformları ifade etmektedir ve büyük işletmeler hem müşterileriyle hem de çalışanlarıyla günlük işlemlerini yapmada bu yöntemi benimsemişlerdir (Guesalaga, 2016: 73). Bununla birlikte, bazı derin teknolojik ve kültürel değişiklikler nedeniyle çevrimiçi topluluklar, parçalanma, yaygınlaşma ve olgunlaşma sürecinden geçerek, YouTube, Facebook ve bloglar gibi birbirine bağlı çevrimiçi topluluklara dönüşmüştür (Weijo, Hietanen ve Mattila, 2014: 2074). Sosyal ağ; ortak bir gaye doğrultusunda kişilerin düşüncelerini paylaşmalarını ve etkileşim ortamına girmelerini kolaylaştıran internet üzerinden yaratılan bir topluluktur (Preeti, 2009: 129). Sosyal ağların katılım, açıklık, konuşma gibi kullanıcılara sağladığı yer ve zaman sınırı olmayan imkanları işletmelerle müşterileri arasındaki iletişimi, çift yönlü simetrik iletişim ortamı haline getirmektedir (Onat, 2010: 105). Dünyada ve Türkiye’de yaygın olarak kullanılan sosyal medya araçları hakkında kısa bir bilgi vermek gerekirse;

Facebook Mark Zuckerberg tarafından 4 Şubat 2004 yılında kurulmuş bir web sitesi, çevrimiçi sosyal ağ hizmeti sunan bir işletmedir. A $\breve{g} 1,59$ milyar üzerinde aylık aktif kullanıcıya sahip olup, 250 milyar dolarlık bir piyasa değerine ulaşarak Standard \& Poor's 500 Endeksindeki yerini çok kısa sürede almıştır (Orzan, Burghelea, Stupu ve Boboc, 2016: 1004).

Twitter, kullanıcıların "tweet" adı verilen kısa mesajları göndermesine ve okumasına izin veren ve bir mesajın uzunluğu 140 karakter olan bir çevrimiçi sosyal ağ hizmetidir. Bir kullanıcı olarak, tweetleri okuyabilir ya da tweet atabilirsiniz, ancak eğer kayıtlı değilseniz yalnızca tweetleri okuyabilirsiniz. Mart 2006'da yaratılan bu sosyal medya kanalı, kurulduktan 4 ay sonra faaliyete geçmiştir. Mayıs 2015 itibariyle, Twitter 500 milyondan fazla kullanıcısına sahiptir ve bunlardan 332 milyondan fazlası etkin kullanıcı durumdadır (Orzan ve diğerleri, 2016: 1004).

LinkedIn, 2002 yılında kurulmuş ve kurulduktan 1 yıl sonra faaliyetlerine başlayan profesyonel ağ temelli kullanılan iş odaklı bir sosyal ağ hizmetidir. 2015'ten itibaren, sitenin gelirlerinin çoğu, işverenler, kullanıcılar hakkında bilgi erişimi sağlayanlar ve satış uzmanlarından elde edilmiştir (Orzan ve diğerleri, 2016: 1004). Linkedln'in hedef kitlesine bakıldığında mesleki nitelikleri açısından ilginç bir hedef kitleye sahiptir. Linkedln'deki ağ bilgileri analiz edilerek, kişiler ve tanıdık insanlar hakkında çok şey öğrenebilirsiniz (Bradbury, 2011: 7).

Instagram, kullanıcıların hayatlarını diğer kullanıcılarla paylaştığı, çevrimiçi fotoğraf paylaşımının yapıldığı en hızlı büyüyen sosyal medya araçlarından birisidir. 2012 yılında kurulan ve 400 milyondan fazla kullanıcısı olduğu bildirilen intagram'ın, reklamlardan elde edeceği gelirin 2017 yılında 2,81 milyar dolara ulaşması beklenmektedir (Djafarova ve Rushworth, 2016: 1). Instagram da 15 Aralık 2016 tarihinde canlı yayın güncellemesi yaparak, giderek kızışan kullanıcı sayısı arttırma rekabetinin içine girmiştir. Stories (hikayeler) özelliğinin ardından live (canlı yayın) özelliğini uygulamaya ekleyerek bu sosyal ağ kendini geliştirmiştir (Yılmaz, 2017: 132). Önceleri sadece fotoğraf paylaşımı yapılan bu sosyal ağda daha sonrasında video paylaşımına da izin vermesiyle, bu özelliğin kullanıma açıldığı ilk 24 saatte 5 milyon adet video paylaşımı olmuştur (Sabuncuğulu ve Göker, 2016: 1139).

Instagram'ın en önemli özelliği kullanıcı deneyimini bozmadan, kullanıcılara rahatsızlık vermeden reklam gösterimi sunmasıdır. Instagram şimdilik, yeni reklam modelleri 
denemektedir. Instagram yapısı gereği gerek bünyesindeki linkler gerek butonlarla hiçbir şekilde dış bağlantı vermeden Instagram'ın reklam verenleri tarafindan kullanıcıların web sitesine yönlendirilmektedirler (Zümrüt, 2016: 41).

YouTube, videoları izlemek için kullanılan bir kaynaktır. 2005 yılında piyasaya çıkan bu medya, Google ve Facebook'dan sonra dünyada en çok ziyaret edilen üçüncü sitedir. YouTube içeriği çok çeşitli ve küresel olup, site ziyaretçilerinin çok geniş bir kitleye içerik yayma firsatı sunmaktadır. Site hem amatör içerik yaratıcıları hem de medya şirketleri için çekici bir platform olarak hizmet ediyor. Politikacılar, haber kuruluşları, eğitim enstitüleri, işletmeler, müzik ve film sanatçıları ve her kesimden insanlar YouTube kullanmaktadır (Khan, 2016: 236).

Son y1llarda pazarlamaya dair faaliyetlerin görünümü, radikal biçimde değişim göstermiştir. Geçmişte hiç olmadığı kadar da çevrimiçi pazarlama baskın hale gelmiştir. İnternetin ilk dönemlerinde yeni medya kanalları gelişirken çevrimiçi medya pazarlama uygulamalarının yoğunluğu \%17 oranlarından 2000'lere gelindiğinde \%70 seviyelerine çıkmıştır (Tuten, 2008: 19).

Örgütler müşteriyle iletişime geçip onlara yardım sağlayarak ve onların tecrübelerinden faydalanmak açısından sosyal medya kullanımlarını günden güne arttırmaktadırlar (Şengöz ve Eroğlu, 2017, 504). Başarılı bir sosyal medya iletişimi için, sunulan hizmetin tipi ve kurumun amaçları gözetilerek bir sosyal medya stratejisi belirlemek önemlidir (Salman ve Eroğlu, 2017: 530). Kullanıcılar bir kurumun sosyal ağ sayfasını (Facebook, Instagram gibi) beğenerek ona olan ilgisini göstermekte ve kurumla ilgili olarak çeşitli bilgi ve gelişmeleri takip etme olanağ1 bulabilmektedir (Safko, 2012: 32-33).

Milyonlarca insanın fiilen bir araya geldiği sosyal ağlar, iletişim ve etkileşim için çok büyük pazarlardır. Sosyal ağlar, pazarlama mesajlarının yayılması, geniş çapta ürün sunumlarının yaratılması ve şirket yönetimleri için mükemmel araçlardır (Dunne, Lawlor \& Rowley, 2010: 48). İnternet üzerinde harcanan zamanın artmasında etkin bir rol oynayan sosyal medya ve tüketicilerin geleneksel mağazalara artık gitmemesi görmezden gelinemeyecek bir gerçektir. Sosyal medya araçları ürünlerin teklif edildiği, firsatların tartışıldığı ve markaların övülüp eleştirildiği yerlere dönüşmüştür. Sosyal medya tüketicilerin karar verme süreçlerini ve satın alma davranışlarını değiştirmektedir (Yemez, 2016: 100). Bu yeni durum karşısında sosyal medyanın, pazarlama iletişim aracı olarak kullanımına yönelik akademik çalışmaların sayısı da hızla artış göstermektedir (Edin, 2016: 59).

Sosyal medya pazarlaması geleneksel pazarlamaya kıyasla, daha karmaşık bir yapıya sahiptir. $\mathrm{Bu}$ karmaşık yapı sosyal medyanın müşterilere içerik oluşturabilme imkânı sağlamasından kaynaklanmaktadır. Dolayısıyla müşterilerin daha etkin olduğu, seslerini daha fazla duyurabildiği çevrimiçi bir ortamın oluşmasına neden oluşturmuştur (Kohli vd., 2015:37). Sosyal medya müşterilere markaların olumsuz yönlerini kolayca duyurabilecekleri yeni çevrimiçi ortamları sunmuştur. Bu nedenle de başlangıçta markalara sosyal medya ortamlarına girmek yerine savunmacı taktikler geliştirmeleri uzmanlarca önerilmekteydi; ancak bu bakış açısı zamanla değişmiş ve markalar sosyal medyanın yarattığı firsatları değerlendirme yoluna gitmiştir (Can, 2017:141).

Sosyal medya işletmecilik anlayışı içerisinde bir pazarlama aracı olarak ele alınmıştır. Araştırmalara göre sosyal medya tutundurma karmasının yeni bir aracıdır. Pazarlama açısından konuyu değerlendiren çoğu akademisyen ve araştırmacı sosyal medyayı geleneksel ağızdan ağza iletişimin dijital bir uygulaması şeklinde değerlendirmişlerdir. Araştırmalara göre sosyal medyada üretilen bilgiler markalar için güçlü ya da tersi imajlar üretmektedir ve bu durum tüketicilerin satın alma kararlarına etki etmektedir (Aydın, 2016: 16-18). Sosyal medya, işletmelere müşterileri ile doğrudan etkileşim kurmalarına, müşterilerin mal ve hizmetler 
hakkındaki düşüncelerinin öğrenilmesine olanak sağlamaktadır (Hvass ve Munar, 2012: 93). İşletme, sosyal medya üzerinden sadece geleneksel pazarlama çalışmalarını çevrimiçi ağ üzerinden uygulamamakta aynı zamanda daha önceden hiç mümkün olmadığı şekilde tüketiciyle doğrudan temas kurabilmektedir (Vinerean vd., 2013: 68).

\section{Reklam}

Amerikan Pazarlama Birliği'nin tanımına göre reklam; herhangi bir malın, hizmetin veya fikrin bedeli ödenerek ve bedelin kim tarafindan ödendiği anlaşılacak biçimde yapılan ve kişisel satışın dışında kalan tanıtım eylemleridir. Bu tanıma göre reklamın dört özelliği vardır (Yoldaş ve Ergezer, 2013: 284);

- Reklam bir bedel karşılığı yapılmaktadır.

- Reklam kişisel bir sunuş değildir, bir mesajı hedef kitleye ulaştırmak için değişik iletişim araçlarının kullanımını gerektiren bir kitle iletişimidir.

- Reklam mesajlarında; mallar, düşünceler ya da hizmetler yer alabilir.

- Reklam yapan kişi ya da kurum bellidir.

Reklam; malları, hizmetleri, organizasyonları ya da fikirlerini beğendirmeyi ve/veya ikna etmeyi amaçlayan işletmeler, kâr amacı gütmeyen organizasyonlar, devlet kurumları ve bireyler tarafindan zaman veya mekânda ilanların ve iletilerin yerleştirilmesidir (Tolon ve Zengin, 2016: 37). Reklam; mal, hizmet ve fikirler hakkında bilgilendirmelerin, yeniliklerin, ikna etme çabalarının ve hatırlatmaların çeşitli kitle iletişim araçlarında belirli bir zaman aralığında ve belirli bir ücret karşılığında yer almasıdır (Gürdin, 2017:19).

Reklamın satışları arttırması hemen olacak bir sonuç değildir. Reklamın etkileri kısa zamanda ortaya çıkabileceği gibi, uzun zaman sonunda da kendini gösterebilir. Potansiyel müşterilerin birer müşteri haline gelmeleri için belli bir süreçten geçmeleri gerekmektedir (Lavidge ve Steiner, 1961: 59).

Reklamın iletişim açısından belirgin özelliği; planlanmış etki veya etkilerin iletinin hedef aldığı kitleyi bir ürün, marka ya da kuruma ilişkin olarak harekete geçirme amacında olmasıdır (Reid, Luxton ve Mavondo, 2005: 11). İyi bir şekilde planlanan ve uygulanan reklamların yaratacağı birçok avantaj vardır. Bu avantajların başlıcaları şunlardır (Pickton ve Broderick, 2001: 458):

1. Geniş kitlelere ulaşabilme;

2. Hedef kitlelere ulaşabilme;

3. Birim maliyetinin düşük olması;

4. Geniş kitlelere ulaşmada ekonomik, etkin ve verimli olma;

5. Marka farkındalı̆̆ oluşturmada başarılı olma.

Reklam ve marka, bu iki kavramın birbirinden bağımsız düşünülemez. Ne markalarımızın reklamsız ne de reklamı yapılan ürünümüzün markasız hayat bulabilmesi olanağı vardır. Çünkü markalarımız bir harf ya da bir amblem olmaktan çok işletme kültürümüzün, kalitemizin, farklılığımızın ve hizmetlerimizin tüketicilere sunulmasını, reklam ise markalarımızın tüketicinin zihninde yer etmesini sağlıyor (Uğur, 2012: 27). David Ogilvy da her reklamın markanın zihinde yer edinmesine katkıda bulunmasının gerektiğini ve 
mesajın, bu yer edinmenin ne olması gerektiği üzerinde odaklanmasını önermektedir (Odabaşı ve Oyman, 2012: 369). Beğenilen reklamlar tüketicinin reklama karşı ilgi duymasını ve markaya karşı da bir beğeni oluşmasını ve satın alma ihtimalinin güçlenmesini sağlar (De Pelsmacker ve diğerleri, 2000: 53).

Çevrimiçi (online) reklamcılık, internet aracılığıyla işletmeler tarafından müşterileri bir mal veya hizmet hakkında bilgilendirmek amacıyla tasarlanmış olan herhangi bir ticari içerik türüdür ve herhangi bir kanal üzerinden (örn. video klibi, basılı veya sesli), herhangi bir türde (örn. bir e-mail mesaj1 veya interaktif bir oyun) iletilebilmekte ve istenilen herhangi bir derinlikte bilgi sunabilmektedir (Özgezmez ve Şakar, 2017: 142).

\section{Amaç ve Yöntem}

\subsection{Araştırmanın Amacı}

Araştırma sosyal ağlarda gerçekleşen pazarlamanın tutundurma faaliyetlerinden biri olan reklamların ă̆ kullanıcıları tarafından dikkat çekiciliğinin ölçümlenmesi amacıyla gerçekleştirilmiştir. Sosyal ağlarda sürekli bir reklam, tanıtım vs. bombardımanı var ve tüketiciye ulaşan bu pazarlama iletileri kullanıcıların ilgisini çekmekte midir yoksa tersine herhangi bir etkisi olmayıp boş bir mesaj yığını mıdır? Sorusunun yanıtı anlaşılmaya çalışılmıştır.

\subsection{Araştırmanın Yöntemi}

Araştırmanın amacı kısmındaki soruya cevap alabilmek için bir anket oluşturulmuş olup, "kolayda örnekleme yöntemi” kullanılarak katılımcılara ulaşılmıştır. Araştırmaya konu sosyal ağ olarak da ülkemizde de yaygın bir biçimde kullanılan Instagram seçilmiş ve hazırlanan anket formu sadece Instagram sosyal ağını kullanan kişilere ulaştırılmıştır. Formda öncelikle katılımcıların demografik özelliklerini belirlemeye ilişkin 6 soru sorulmuş ve ardından 8 adet betimsel soru ile anket devam etmiştir. Son olarak da Instagram kullanıcılarının bu sosyal ağdaki yapılan reklamların fark edilirliğinin belirlenmesi amacıyla 28 adet önerme (Likert tipi ölçek soruları- 5: Kesinlikle katılıyorum, 1: Kesinlikle katılmıyorum) yöneltilerek "Reklamların fark edilirliğì" ölçeği oluşturulmuştur. Anket soruları hazırlanırken Köksal (2012), Akkaya (2013), Akyol (2010) ve Tezcan (2013)'ın araştırmalarına başvurulmuştur. Elde edilen 153 adet veri SPSS 21 paket programında sınamaya alınmıştır.

\subsection{Araştırmanın Temel Hipotezi}

Araştırmanın amacı bölümünde de anıldığı gibi bu inceleme ile Instagram sosyal ağı ortamında yapılan reklamların kullanıcılarının dikkatini çekip çekmediğinin belirlenmesi için gerçekleştirilmektedir. Bu çerçevede reklamların tüketicilerin dikkatini çekmediğini savunan yokluk $\left(\mathrm{H}_{0}\right)$ hipotezi ile aksine dikkat çektiğini savunan alternatif $\left(\mathrm{H}_{1}\right)$ hipotezden hangisinin olduğu anlaşılmaya çalışılacaktır. Çalışmanın bu amacına göre temel hipotezi de aşağıdaki gibidir;

$\mathrm{H}_{0}$ : Sosyal ağlar ortamında gerçekleşen reklamlar tüketicilerin dikkatini çekmemektedir.

$\mathrm{H}_{1}$ : Sosyal ağlar ortamında gerçekleşen reklamlar tüketicilerin dikkatini çekmektedir. 


\subsection{Araştırma Ölçeğinin Güvenilirliği}

Araştırmada kullanılan 28 adet ölçek önermesinin güvenilirlik düzeyinin belirlenebilmesi amacıyla Cronbach's Alpha değerine bakılmıştır ve bu değer 0,886 olarak bulunmuştur. Çıkan bu sonuç araştırmada kullanılan ölçeğin güvenilirlik düzeyinin yüksek olduğunu göstermektedir. Tablo 1'de bahsedilen sınama sonucu yer almaktadır.

Tablo 1: Araştırma Ölçeğinin Güvenilirliği

\begin{tabular}{|c|c|}
\hline Cronbach's Alpha Katsayısı & Madde Sayısı \\
\hline, 886 & 28 \\
\hline
\end{tabular}

\subsection{Sosyal Medya Reklamları Ölçeğine İlişkin Faktör (Temel Bileşenler) Analizi}

Öncelikle "Sosyal Medya Reklamları Ölçeği” adlı ölçeğin sınama için geçerli bir ölçek olup olmadığının belirlenebilmesi maksadıyla KMO ve Bartlett testleri gerçekleştirilmiş olup, KMO değeri (Kaiser-Meyer-Olkin Measure of Sampling Adequacy) 0,733 ve Bartlett değeri (Test of Sphericity) 0,000 bulunmuştur. Elde edilen sonuçlar faktör analizi kullanımı açısından elverişlidir, bu nedenle de faktör analizi gerçekleştirilebilir. Tablo 2'de bahsedilen sınama sonucu yer almaktadir.

Tablo 2: KMO ve Bartlett's Test Sonucu

\begin{tabular}{|c|c|c|}
\hline $\begin{array}{l}\text { Kaiser-Meyer-Olkin } \\
\text { Adequacy. }\end{array}$ & Measure of Sampling &, 733 \\
\hline \multirow{3}{*}{$\begin{array}{l}\text { Bartlett's Test of } \\
\text { Sphericity }\end{array}$} & Approx. Chi-Square & 2978,671 \\
\hline & df & 378 \\
\hline & Sig. &, 000 \\
\hline
\end{tabular}

Ölçekteki 28 önerme faktör analizine alınmıştır ve analiz sonucu 6 faktör ortaya çıkmıştır. "Reklamların fark edilirliği" ölçeği için elde edilen bu 6 faktör toplam varyansın \%70,819'unu açıklamaktadır. Faktör 1'e "Reklamların dikkat çekiciliği”, faktör 2'ye "Markaların dikkat çekiciliği", faktör 3'e "Reklamların akılda kalıcılığı", faktör 4'e "Reklamlara karşı olumsuz tutum", faktör 5'e "Reklamların satın almaya teşvik ediciliği" ve faktör 6'ya "Reklamların bilgi vericiliği" adları konulmuştur. Faktör 4 isminden de anlaşılacağı gibi ters önermelerden oluşmaktadır.

\section{Bulgular}

\subsection{Katılımcıların Demografik Özellikleri}

Katılımcıların \%47,1’i kadın, \%52,9’u erkektir. \%25,5’i 25-34 yaş; \%13,7’si 55 yaş ve üstü aralıktadır. Katılımcıların \%47,1’i evli, \%52,9’u bekardır. Eğitim durumuna bakıldığında katılımcıların \%5,9'u ortaokul, \%49'u üniversitedir. Mesleklerine bakıldığında \%21,6'sı 
memurdur. Hane gelir durumu açısından katılımcıların \%7,8'i 1404 TL altı, \%17,6'sı 5501 TL ve üstü gelire sahiptir. Tablo 3’te bahsedilen sonuçlar görülmektedir.

Tablo 3: Katılımcıların Demografik Özellikleri

\begin{tabular}{|c|c|c|c|}
\hline & & $\mathrm{N}$ & $\%$ \\
\hline \multirow[b]{2}{*}{ Cinsiyet } & Kadın & 72 & 47,1 \\
\hline & Erkek & 81 & 52,9 \\
\hline \multirow{5}{*}{ Yaş } & $18-24$ & 45 & 29,4 \\
\hline & $25-35$ & 39 & 25,5 \\
\hline & $36-45$ & 24 & 15,7 \\
\hline & $46-55$ & 24 & 15,7 \\
\hline & $55+$ & 21 & 13,7 \\
\hline \multirow[b]{2}{*}{ Medeni hal } & Bekar & 72 & 47,1 \\
\hline & Evli & 81 & 52,9 \\
\hline \multirow{5}{*}{ Eğitim durumu } & İlkokul & 0 & 0 \\
\hline & Ortaokul & 9 & 5,9 \\
\hline & Lise & 51 & 33,3 \\
\hline & Üniversite & 75 & 49,0 \\
\hline & Lisansüstü & 18 & 11,8 \\
\hline \multirow{9}{*}{ Meslek } & İşçi-Çiftçi & 18 & 11,8 \\
\hline & Memur & 33 & 21,6 \\
\hline & Öğrenci & 36 & 23,5 \\
\hline & Ev kadını & 3 & 2,0 \\
\hline & Yönetici & 12 & 7,8 \\
\hline & Uzman (Dr., mühendis, avukat vs.) & 6 & 3,9 \\
\hline & Esnaf-Tüccar & 24 & 15,7 \\
\hline & İșsiz & 9 & 5,9 \\
\hline & Diğer & 12 & 7,8 \\
\hline \multirow{5}{*}{ Hane gelir durumu } & 1404 TL ve alt1 & 12 & 7,8 \\
\hline & $1405-2500 \mathrm{TL}$ & 51 & 33,3 \\
\hline & $2501-3500$ & 48 & 31,4 \\
\hline & $3501-4500$ & 15 & 9,8 \\
\hline & 4501 TL ve üstü & 27 & 17,6 \\
\hline
\end{tabular}




\subsection{Instagram'la İlgili Betimsel İstatistikler}

Araştırmada yöneltilen betimsel sorularla ilgili çıkan sonuçlar incelendiğinde; katılımcıların \%64,7'si her gün Instagram'a giriş yapmakta ve \%43,1'i 1-3 saat aras1 vakit geçirmektedir. Katılımcılarının \%78,4'ü Instagram'da dikkatini çeken herhangi bir reklam olduğunu söylemekte, \%39,2'si profilinde reklam paylaşmış, \%60,8'i reklamdaki ürünle ilgili ayrıntılı bilgi elde etmiş, \%56,9'u hesabında bazı markaları takip etmekte, \%45,1'i Instagram'da görüp bir ürün satın almış ve \%52,9'u Instagram'da gördüğü bir ürün ya da markayı çevresine önermiştir.

Tablo 4: Instagram'la İlgili Betimsel İstatistikler

\begin{tabular}{|c|c|c|c|}
\hline & & $\mathbf{N}$ & $\%$ \\
\hline \multirow{4}{*}{ Instagram'a giriş yapma sıklığ } & Her gün & 99 & 64,7 \\
\hline & 2-3 günde bir & 33 & 21,6 \\
\hline & 4-5 günde bir & 21 & 13,7 \\
\hline & Haftada bir & 0 & 0 \\
\hline \multirow{4}{*}{ Instagram'da haftada geçirilen ortalama vakit } & 1 saatten az & 36 & 23,5 \\
\hline & 1-3 saat aras1 & 66 & 43,1 \\
\hline & 4-6 saat aras1 & 18 & 11,8 \\
\hline & $\begin{array}{l}6 \text { saatten } \\
\text { fazla }\end{array}$ & 33 & 21,6 \\
\hline \multirow{2}{*}{ Instagram'da dikkat çeken bir reklam olup olmadiğ 1} & Evet & 120 & 78,4 \\
\hline & Hayır & 33 & 21,6 \\
\hline \multirow{2}{*}{$\begin{array}{l}\text { Instagram'daki bir reklamın profil sayfasında paylaşılıp } \\
\text { paylaşılmadığ } 1\end{array}$} & Evet & 60 & 39,2 \\
\hline & Hayir & 93 & 60,8 \\
\hline \multirow{2}{*}{$\begin{array}{l}\text { Instagram'da dikkat çeken reklamdaki ürünle ilgili ayrıntılı } \\
\text { bilgi edilip edilmediği }\end{array}$} & Evet & 96 & 62,7 \\
\hline & Hayır & 57 & 37,3 \\
\hline \multirow{2}{*}{ Instagram hesabında takip edilen markalar olup olmadığ 1} & Evet & 87 & 56,9 \\
\hline & Hayır & 66 & 43,1 \\
\hline \multirow{2}{*}{$\begin{array}{l}\text { Instagram'da reklamını görerek satın alınan ürün/ürünler } \\
\text { olup olmadığı }\end{array}$} & Evet & 69 & 45,1 \\
\hline & Hayır & 84 & 54,9 \\
\hline \multirow{2}{*}{$\begin{array}{l}\text { Instagram'da reklamı görülen ürünlerin/markaların çevreye } \\
\text { tavsiye edilip edilmediği }\end{array}$} & Evet & 81 & 52,9 \\
\hline & Hayır & 72 & 47,1 \\
\hline
\end{tabular}

\subsection{Araştırma Faktörlerinin Ortalaması}

"Reklamların fark edilirliği” için oluşturulan 6 faktörün ortalamaları aşağıdaki Tablo 5.'de verilmiştir. Önceden bahsedildiği gibi 4. Faktör olan "Reklamlara karşı olumsuz tutum” faktörü ters ölçek önermelerden oluştuğu için analiz sırasında tersten $(1=5,2=4,4=2,5=1)$ kodlanmıştır. Dolayısıyla da bu faktörün ortalaması dahil tüm ortalamaların 3 rakamından büyük çıkması faktörler için olumlu bir neticedir. Tablo 5.' de görülmektedir ki tüm faktörlerin ortalamaları 3 rakamından büyüktür. 
Tablo 5: Araştırma Faktörlerinin Ortalaması

\begin{tabular}{|l|c|c|}
\hline & N & Mean \\
\hline Reklamların dikkat çekiciliği & 153 & 3,4174 \\
Markaların dikkat çekiciliği & 153 & 3,6961 \\
Reklamların akılda kalıcılığı & 153 & 3,7010 \\
Reklamlara karşı olumsuz tutum & 153 & 3,2108 \\
Reklamların satın almaya teşvik ediciliği & 153 & 3,4706 \\
Reklamların bilgi vericiliği & 153 & 3,6863 \\
\hline
\end{tabular}

\subsection{Gruplar Arasında Anlamlı Farklılık Olup Olmadığına Dair Sınamalar}

\subsection{Bağımsız Örneklem T Testi}

İki grupta yapılan ölçümlerin ortalamasının kıyaslandığı "bağımsız örneklem t testi” ile katılımcıların cinsiyet ve medeni hallerine göre "Reklamların fark edilirliği" ölçeği için verdikleri yanıtlarda gruplar arasında olabilecek anlamlı bir farklılığın tespit edilebilmesi amacıyla bağımsız örneklem $t$ testi uygulanmıştır. Bu sınamaya ilişkin hipotezlerimiz;

Varyansların eşit olup olmadığı;

$$
\begin{aligned}
& H_{0}: \sigma_{1}{ }^{2}=\sigma_{2}{ }^{2} \\
& H_{1}: \sigma_{1}{ }^{2} \neq \sigma_{2}{ }^{2}
\end{aligned}
$$

Grup ortalamaları arasında farklılık olup olmadığı;

$$
\begin{aligned}
& \mathrm{H}_{0}: \mu 1=\mu 2 \\
& \mathrm{H}_{1}: \mu 1 \neq \mu 2
\end{aligned}
$$

Cinsiyet açısından gruplar arasında anlamlı bir fark olup olmadığının anlaşılması için yapılan test sonucunda "Reklamların dikkat çekiciliği" ( $(\mathrm{p}=0,922)$, "Reklamların akılda kalıcılığıı" ( $p=0,232)$, "Reklamlara karşı olumsuz tutum” ( $p=0,1399$, "Reklamların satın almaya teşvik ediciliği" ( $p=0,980)$ ve "Reklamların bilgi vericiliği" ( $p=0,233)$ faktörleri için $p>\alpha$ ( $>0,05)$ ' dır. "Markaların dikkat çekiciliği”" faktörü için ise; $p$ değeri 0,004 olup 0,05 'ten küçüktür. Verilen istatistiki sonuçlara göre "Markaların dikkat çekiciliğgi" faktörü için $\mathrm{H}_{0}$ hipotezimiz reddedilebilmekte, diğer 5 faktör içinse reddedilememektedir. "Markaların dikkat çekiciliği” faktörü için kadınların ortalaması 3,4688 iken, erkeklerin ortalaması 3,8981'dir.

Medeni hal bakımından "Markaların dikkat çekiciliği”" $(p=0,000)$ ve "Reklamlara karşı olumsuz tutum” ( $\mathrm{p}=0,003)$ faktörleri için $\mathrm{H}_{0}$ hipotezimiz reddedilebilmekte, diğer 4 faktör için reddedilememektedir. "Markaların dikkat çekiciliğgi" faktörü için evlilerin ortalaması 3,9688, bekarların ortalaması 3,4537 ve "Reklamlara karşı olumsuz tutum" için evlilerin ortalaması (ters kodlama sonucunda) 3,2917, bekarların ortalaması 3,1389'dur. 
Tablo 6: "Reklamların Fark Edilirliğgi” Ölçeği Faktörlerinin Medeni Hal Açısından Farklılık Gösterip Göstermediğine Dair Bağımsız Örneklem T Test

\begin{tabular}{|c|c|c|c|c|c|}
\hline \multirow{2}{*}{\multicolumn{2}{|c|}{ Faktörler }} & \multicolumn{2}{|c|}{ Levene Testi } & \multicolumn{2}{|c|}{ T Testi } \\
\hline & & $\mathbf{F}$ & Sig. & $\mathbf{T}$ & Sig (2-tailed) \\
\hline \multirow{2}{*}{ Reklamların dikkat çekiciliği } & V.e.v & \multirow[t]{2}{*}{1,084} & \multirow[t]{2}{*}{,300 } &,- 627 & ,532 \\
\hline & V.e.o.v & & &,- 629 &, 530 \\
\hline \multirow{2}{*}{ Markaların dikkat çekiciliği } & V.e.v & \multirow[t]{2}{*}{20,346} & \multirow[t]{2}{*}{,000 } & 3,622 &, 000 \\
\hline & V.e.o.v & & & 3,709 &, 000 \\
\hline \multirow{2}{*}{ Reklamların akılda kalıcılığı } & V.e.v & \multirow[t]{2}{*}{,389 } & \multirow[t]{2}{*}{, 534} & $-1,025$ & ,307 \\
\hline & V.e.o.v & & & $-1,023$ & ,308 \\
\hline \multirow{2}{*}{$\begin{array}{l}\text { Reklamlara karşı olumsuz } \\
\text { tutum }\end{array}$} & V.e.v & \multirow[t]{2}{*}{1,650} & \multirow[t]{2}{*}{ 201 } & 3,062 & ,003 \\
\hline & V.e.o.v & & & 3,094 & ,002 \\
\hline \multirow{2}{*}{$\begin{array}{l}\text { Reklamların satın almaya } \\
\text { teşvik ediciliği }\end{array}$} & V.e.v & \multirow[t]{2}{*}{2,184} & \multirow[t]{2}{*}{,142 } &,- 770 & ,443 \\
\hline & V.e.o.v & & &,- 777 & ,438 \\
\hline \multirow{2}{*}{ Reklamların bilgi vericiliği } & V.e.v & \multirow[t]{2}{*}{2,949} & \multirow[t]{2}{*}{,088 } & ,901 & ,369 \\
\hline & V.e.o.v & & & ,908 & ,365 \\
\hline
\end{tabular}

V.e.v: Varyanslar eşit varsayıldığında; V.e.o.v: Varyanslar eşit değil varsayıldığında

\subsubsection{Tek Yönlü Varyans Analizi}

"Reklamların fark edilirliği” ölçeği faktörlerinin yaş, eğitim, meslek ve hane gelir durumu için gruplar arasındaki farklılığın anlamlılığını test edebilmek için gerçekleştirilen Tek Yönlü Varyans Analizi’nin hipotezleri;

$\mathrm{H}_{0}: \mu 1=\mu 2=\mu 3=\mu 4=\mu 5$

$\mathrm{H}_{1}$ : $\mu \mathrm{j}$ 'lerden ez biri diğerlerinden farklıdır

Yaş değişkenine ait sonuçlarda; "Reklamların satın almaya teşvik ediciliği” faktöründe $\mathrm{p}=0,003$ 'dür. Diğer 5 değişken için $\mathrm{p}>\alpha$ 'dır. Bu sonuçlara göre "Reklamların satın almaya teşvik ediciliğì" faktörü için $\mathrm{H}_{0}$ hipotezimiz reddedilebilmekte, diğer 5 faktör için ise reddedilememektedir. Yapılan Post Hoc testinde bu farklılığın 45-54 yaş grubuyla 18-24, 2534 ve 35-44 yaş grupları arasında olduğu sonucu çıkmıştır.

Eğitim değişkenine ait gruplar için; "Reklamların dikkat çekiciliği”, "Markaların dikkat çekiciliği", "Reklamların akılda kalıcılığı" ve "Reklamlara karşı olumsuz tutum" faktörlerine ait $\mathrm{p}<\alpha$ olup bu 4 faktör için $\mathrm{H}_{0}$ hipotezimiz reddedilebilmektedir. "Reklamların dikkat çekiciliği" faktöründe bu farklılık ortaokul grubuyla üniversite grubu arasında, "Markaların dikkat çekiciliği” faktöründe üniversite ile lise ve lisansüstü grupları arasındadır. "Reklamların akılda kalıcılığı" faktöründe lise ve üniversite grupları arasında, "Reklamlara karşı olumsuz tutum" faktöründeyse ortaokulla lise ve üniversite grupları arasındadır.

Meslek açısından "Reklamların dikkat çekiciliği”, "Markaların dikkat çekiciliği” ve "Reklamların akılda kalıcılığı" faktörlerinde $p>\alpha$ sonucu çıkmış, her 3 faktör içinde $p=0,000$ 
olup $\mathrm{H}_{0}$ hipotezimiz reddedilebilmektedir. "Reklamların dikkat çekiciliği” faktörü açısından bu anlamlı farklılık mesleği uzman (Dr., mühendis, avukat vs.) grubu ile memur ve öğrenci grupları arasındadır. "Markaların dikkat çekiciliğii" faktöründe ise; öğrenci grubuyla işçi-çiftçi, uzman (Dr., mühendis, avukat vs.), esnaf-tüccar ve diğer grupları arasındadır. "Reklamların akılda kalıcılı̆̆gı" faktörü için gruplar arasındaki anlamlı farklılık; işçi-çiftçi ile işsiz, memurla işsiz ve yönetici, öğrenci ile yönetici, ev kadınıyla işsiz grupları arasındadır.

Tablo 7: "Reklamların Fark Edilirliği” Ölçeği Faktörlerinin Meslek Değişkenine Ait ANOVA Testi Sonuçları

\begin{tabular}{|c|c|c|c|c|}
\hline \multicolumn{2}{|l|}{ Faktörler } & df & $\mathbf{F}$ & Sig. \\
\hline Reklamların dikkat çekiciliği & $\begin{array}{l}\text { Gruplar Arasinda } \\
\text { Gruplar İçerisinde } \\
\text { Toplam }\end{array}$ & $\begin{array}{l}8 \\
144 \\
152\end{array}$ & 3,792 &, 000 \\
\hline Markaların dikkat çekiciliği & $\begin{array}{l}\text { Gruplar Arasinda } \\
\text { Gruplar İçerisinde } \\
\text { Toplam }\end{array}$ & $\begin{array}{l}8 \\
144 \\
152\end{array}$ & 5,179 &, 000 \\
\hline Reklamların akılda kalıcılığı & $\begin{array}{l}\text { Gruplar Arasinda } \\
\text { Gruplar İçerisinde } \\
\text { Toplam }\end{array}$ & $\begin{array}{l}8 \\
144 \\
152\end{array}$ & 6,900 & ,000 \\
\hline $\begin{array}{l}\text { Reklamlara karşı olumsuz } \\
\text { tutum }\end{array}$ & $\begin{array}{l}\text { Gruplar Arasinda } \\
\text { Gruplar İçerisinde } \\
\text { Toplam }\end{array}$ & $\begin{array}{l}8 \\
144 \\
152\end{array}$ & 1,403 & ,200 \\
\hline $\begin{array}{l}\text { Reklamların satın almaya } \\
\text { teşvik ediciliği }\end{array}$ & $\begin{array}{l}\text { Gruplar Arasinda } \\
\text { Gruplar İçerisinde } \\
\text { Toplam }\end{array}$ & $\begin{array}{l}8 \\
144 \\
152\end{array}$ & 1,767 & ,088 \\
\hline Reklamların bilgi vericiliği & $\begin{array}{l}\text { Gruplar Arasında } \\
\text { Gruplar İçerisinde } \\
\text { Toplam }\end{array}$ & $\begin{array}{l}8 \\
144 \\
152\end{array}$ & 1,151 & 333 \\
\hline
\end{tabular}

Hane gelir durumu değişkeninde; "Reklamların dikkat çekiciliği” ve "Reklamların akılda kalıcılığı" faktörlerinin $\mathrm{p}>\alpha$ olduğu görülmüştür. Söz konusu faktörler için $\mathrm{H}_{0}$ hipotezimiz reddedilemez. "Reklamların dikkat çekiciliği" faktörü için 1405-2500 ile 5501 TL ve üstü grupları arasında, "Reklamların akılda kalıcılığı" faktörü için 1404 TL ve altı ile 5501 TL ve üstü grupları arasında anlamlı bir farklılık olduğu sonucu çıkmıştır. 


\subsection{Instagram’la İlgili Betimsel İstatistikler ile Faktörler Arasındaki Korelasyon}

Korelasyon analizi ile araştırmada katılımcılara yöneltilen betimsel sorularla "Reklamların fark edilirliği” ölçeğine ait faktörler arasında ilişkinin var olup olmadığı anlaşılmaya çalışılmıştır. Gruplar normal dağılıma uygun olduğundan burada Pearson korelasyon sonuçları dikkate alınarak değerlendirme yapılmıştır. Analizimize ait hipotezlerimiz;

$\mathrm{H}_{0}$ : Değişkenler arasında ilişki yoktur.

$\mathrm{H}_{1}$ : Değişkenler arasında ilişki vardır.

Tablo 8. için sonuçlara göz atıldığında “Instagram'da dikkat çeken bir reklam olup olmadığg" sorusuyla tüm faktörler arasında bir ilişki olduğu görülmektedir. "Markaların dikkat çekiciliği" faktörüyle olan ilişki $(r=0,703)$ aynı doğrusal yönde ve yüksek kuvvetedir. Buna karşın "Reklamların akılda kalıcılığı" faktörüyle olan ilişkinin yönü aynı olmakla birlikte zayıf derecede kuvvete sahiptir $(\mathrm{r}=0,289)$. Ters önermelerden oluşan "Reklamlara karşı olumsuz tutum” faktörü için r=-0,561 olup ters yönde ve orta kuvvette ilişki vardır. "Instagram’daki bir reklamın profil sayfasında paylaşılıp paylaşılmadı̆̆ı" sorusu için "Reklamların akılda kalıcılığı" ile aynı yönlü ve çok zayıf kuvvette ilişkiye, "Reklamlara karşı olumsuz tutum" faktörüyle ters yönde ve zayıf kuvvette, diğer 4 faktörle aynı yönde ve zayıf kuvvette ilişkiye sahiptir. "Instagram'da dikkat çeken reklamdaki ürünle ilgili ayrıntılı bilgi edilip edilmediği" sorusuyla "Reklamların satın almaya teşvik ediciliğii" faktörü arasındaki ilişkinin değeri r=,097 ve $p=0,234$ olup bu iki değişken arasında ilişkinin varlığından söz edilememektedir. "Instagram hesabında takip edilen markalar olup olmadığı" sorusuyla "Reklamların dikkat çekiciliği" ve "Reklamların satın almaya teşvik ediciliği" faktörleri arasında da bir ilişki yoktur. "Instagram'da reklamını görerek satın alınan ürün/ürünler olup olmadığı” değişkeniyle "Reklamların akılda kalıcılığı" ve "Reklamlara karşı olumsuz tutum" için ilişki açısından $p>\alpha$ olup herhangi bir ilişkinin olmadığı varsayılmaktadır. "Instagram'da reklamı görülen ürünlerin/markaların çevreye tavsiye edilip edilmediği" değişkeniyle "Reklamlara karşı olumsuz tutum" değişkeni arasında ters yönlü ve zayıf kuvvette ilişki varken, diğer 5 faktör açısından aynı yönlü ve zayıf kuvvette ilişki var olmaktadır.

Tablo 8: Betimsel İstatistikler İle Faktörler Arasındaki Korelasyon

\begin{tabular}{|c|c|c|c|c|c|c|c|}
\hline & & $\begin{array}{l}\text { Reklamların } \\
\text { dikkat } \\
\text { çekiciliği }\end{array}$ & $\begin{array}{l}\text { Markaların } \\
\text { dikkat } \\
\text { çekiciliği }\end{array}$ & $\begin{array}{l}\text { Reklamların } \\
\text { akılda } \\
\text { kalıcılığg }\end{array}$ & $\begin{array}{l}\text { Reklamlara } \\
\text { Karş1 } \\
\text { olumsuz } \\
\text { tutum }\end{array}$ & $\begin{array}{l}\text { Reklamların } \\
\text { satın almaya } \\
\text { teşvik ediciliği }\end{array}$ & $\begin{array}{l}\text { Reklamların } \\
\text { bilgi } \\
\text { vericiliği }\end{array}$ \\
\hline \multirow{2}{*}{$\begin{array}{l}\text { Instagram’da dikkat } \\
\text { çeken bir reklam }\end{array}$} & Pearson &, $531^{* *}$ &, $703^{* *}$ &, $289^{* *}$ &,$- 561^{* *}$ &, $611^{* *}$ &, $558^{* *}$ \\
\hline & Sig. &, 000 &, 000 &, 000 &, 000 &, 000 &, 000 \\
\hline \multirow{2}{*}{$\begin{array}{l}\text { Instagram’daki bir } \\
\text { reklamın profil }\end{array}$} & Pearson &, $412^{* *}$ &, $313^{* *}$ &, $189^{*}$ &,$- 418^{* *}$ &, $437^{* *}$ &, $220^{* *}$ \\
\hline & Sig. &, 000 &, 000 &, 019 &, 000 &, 000 &, 006 \\
\hline \multirow{2}{*}{$\begin{array}{l}\text { Instagram’da dikkat } \\
\text { çeken reklamdaki }\end{array}$} & Pearson &, $262^{* *}$ &, $411^{* *}$ &, $413^{* *}$ &,$- 409^{* *}$ &, 097 &, $356^{* *}$ \\
\hline & Sig. &, 001 &, 000 &, 000 &, 000 &, 234 &, 000 \\
\hline \multirow{2}{*}{$\begin{array}{l}\text { Instagram hesabında } \\
\text { takip edilen markalar }\end{array}$} & Pearson & 153 &, $188^{*}$ &, $216^{* *}$ &,$- 351^{* *}$ &, 109 &, $308^{* *}$ \\
\hline & Sig. &, 058 &, 020 &, 007 &, 000 &, 180 &, 000 \\
\hline \multirow{2}{*}{$\begin{array}{l}\text { Instagram'da } \\
\text { reklamını görerek } \\
\text { catin }\end{array}$} & Pearson &, $408^{* *}$ &, $213^{* *}$ &, 158 &,- 092 &, $336^{* *}$ &, $299^{* *}$ \\
\hline & Sig. &, 000 &, 008 &, 052 &, 256 &, 000 &, 000 \\
\hline
\end{tabular}




\begin{tabular}{|ll|l|l|l|l|l|l|}
\hline $\begin{array}{l}\text { Instagram'da reklamı } \\
\text { görülen ürünlerin/ }\end{array}$ & Pearson &, $301^{* *}$ &, $290^{* *}$ &, $317^{* *}$ &,$- 373^{*}$ &, $365^{* *}$ &, $414^{* *}$ \\
\hline
\end{tabular}

**. Correlation is significant at the 0.01 level (2-tailed).

*. Correlation is significant at the 0.05 level (2-tailed).

“Instagram’da dikkat çeken reklamdaki ürünle ilgili ayrıntılı bilgi edilip edilmediği” değişkeniyle "Reklamların satın almaya teşvik ediciliği" faktörü için, "Instagram hesabında takip edilen markalar olup olmadı̆̆ı" değişkeniyle "Reklamların dikkat çekiciliği" ve "Reklamların satın almaya teşvik ediciliği” faktörleri için, "Instagram'da reklamını görerek satın alınan ürün/ürünler olup olmadığı”" değişkeniyle "Reklamların akılda kalıcılığı" ve "Reklamlara karşı olumsuz tutum" faktörleri için $\mathrm{H}_{0}$ hipotezimiz reddedilememektedir. Diğer tüm kurulan modeller için ise, $\mathrm{H}_{0}$ hipotezimiz reddedilebilmektedir.

\section{Sonuç}

Pazarlama iletişimi olarak adlandırılan kavram; bir kuruluşun varoluşuyla, mal ve hizmetleriyle ilişkide bulunduğu ve bulunacağı tüm kesimlere neler vaat ettiğini, neler sağlayabileceğini anlatmasını sağlayacak iletişim çabalarının tümü (Kocabaş, Elden ve Çelebi, 2000: 15-16) olduğuna göre; işletmelerin mal ve hizmetlerini tutundurmak için fayda sağlayabileceği hemen hemen her medya aracını kullanması ve bu ortamlarla gerçek ve potansiyel müşterilerine iletilerini göndermesi elbette ki gerçekleştirmesi gereken bir çabadır.

İşletmelerin ürünlerini tutundurma faaliyetlerini gerçekleştirmesi için sosyal medya günümüzün önemli bir pazarlama iletişimi unsuru olmaya başlamıştır. Çünkü bireyler günlük haberleri, çevresindeki insanların neler yaptığını öğrenmek, kendi yaptıklarından etrafı haberdar etmek için bu ortamı sıkça kullanır konuma gelmiştir. Bunu sonucu olarak da işletmeler/markalar kişilerin sık sık çevrim içi olup oldukça kayda değer derecede vakit geçirdikleri sosyal ağ ortamlarında ürünlerini tutundurma işlemlerine girişmektedirler. Peki, bu ortamlarda gerçekleşen reklam çabaları sosyal ă̆ kullanıcıların dikkatini gerçekten de çekmekte midir? Ya da dikkatlerini çekiyorsa ne kadar çekmektedir? Bu dikkat çekmeye karşılık bir davranış değişikliği göstermekte midirler? Araştırmacılar bu tür soruların yanıtlarını aydınlığa kavuşturabilmek için bir araç olabilecek olan sosyal medyada reklam uygulamalarına yönelik bu çalışmayı gerçekleştirmişlerdir.

Araştırmada katılımcıların \%64,7'sinin her gün Istagram'a girdiği, \%78,4'ünün bu sosyal ağda dikkatini çeken bir reklam olduğu, \%45,1'inin Instagram'dan reklamını görüp bir ürün satın aldığı, \%60,8'i reklamdaki ürünle ilgili ayrıntılı bilgi elde ettiği görülmüştür. Ayrıca araştırmada ölçek önermelerinden elde edilen elde edilen tüm faktörlerin ortalaması ("Reklamlara karşı olumsuz tutum" faktörü ters kodlanmıştır) 3'ten büyüktür. Bu sonuç ortalamaların faktörler lehine olduğunu göstermektedir. Özellikle "Markaların dikkat çekiciliği” (3,6961) ve "Reklamların akılda kalıcılığı" $(3,7010)$ faktörlerinin ortalamalarının 4'e yakın olması Instagram sosyal ağındaki reklamların katılımcıların ürünü/markayı fark etmesinde ve hafizalarında yer edinilmesinde etkin bir rolü olduğunun göstergesidir.

Ortalamaları dikkat çekici olan bazı önermelere de kısaca değinilecek olursa, “Instagram’daki reklamlar markayı/ürünü fark etmemi sağlar” önermesinin ortalaması 3,80; "Instagram'daki reklamlar markayı tekrar anımsamamı sağlamaktadır” 3,86; "Ürünü/markayla dışarıda karşılaştığımda Instagram'da reklamını gördüğüm aklıma gelir" 4,00 ortalamayla göze çarpmaktadır. Ayrıca ters ölçek önermeleri olan 'Instagram'da gördüğüm reklamlar aklımda 
kalmaz hemen unuturum" önermesinin 3,24; "Instagram'da reklam olmasını istemem" önermesinin 3,51; “Instagram' dayken reklam yapıldığının farkına varmam" önermesinin 3,63 ortalaması vardır ve bu sonuçlarda araştırma sırasında ters kodlandığı için 3 rakamından büyük olduğundan önermelerin lehine değildir. Buna rağmen "Instagram'da karşıma reklam çıktığında reklamı merak etmem hemen geçerim" önermesinin ortalaması 2,94 olup burada önerme lehinedir.

Betimsel istatistikler ile araştırma ölçeğine ("Reklamların fark edilirliği” ölçeği) ait faktörler arasındaki korelasyona bakıldığında; "İnstagram'da dikkat çeken reklamdaki ürünle ilgili ayrıntılı bilgi edilip edilmediği" değişkeniyle "Reklamların satın almaya teşvik ediciliği”" değişkeni arasında, "İnstagram hesabında takip edilen markalar olup olmadığı" değişkeniyle "Reklamların dikkat çekiciliğii" ve "Reklamların satın almaya teşvik ediciliği" değişkenleri arasında, "İnstagram'da reklamını görerek satın alınan ürün/ürünler olup olmadığı" değişkeniyle "Reklamların akılda kalıcılığı" ve "Reklamlara karşı olumsuz tutum” değişkenleri arasında korelasyon bulunmamaktadır. Bu ifade edilenler haricindeki tüm kurulan modellerde değişkenler arasında korelasyon var olmaktadır. "Reklamların bilgi vericiliğgi" faktörüyle Instagram'da bir reklamın dikkat çekmesi arasında 0,558 'lik ve bu ürün ya da markanın çevreye tavsiye edilmesi arasında 0,414'lük bir korelasyon bulunmaktadır. "Reklamların satın almaya teşvik edici" olmasıyla bu reklamları kullanıcıların fark etmesi ve profillerinde paylaşması arasında sirasıyla 0,611 'lik ve $0,0,437$ 'lik bir korelasyon vardır. "Reklamların akılda kalıcılığı" faktörüyle reklamlarla ilgili daha fazla bilgi elde edinilmesi arasında 0,413'lük, "Markaların dikkat çekiciliği” faktörüyle bu markalara ait reklamların dikkat çekiciliği arasında 0,703'lük, reklamların dikkat çekici olmasıyla ürünün satın alınması arasında 0,408'lik korelasyon olduğu görülmektedir.

Korelasyon analizi neticeleri açısından Instagram'da markalara ait reklamların daha dikkat çekici olduğu belirtilebilir. Bu iki değişken arasındaki ilişkinin kuvveti yüksektir. Reklamlara karşı kullanıcının tutumu olumlu yönde olduğunda, Instagram'daki reklamlar daha fark edilir olmakta, kullanıcılar sayfalarında bunu paylaşmakta ve ürün/marka hakkında daha fazla bilgi sahibi olmak istemektedir. Reklamların dikkat çekici olması ve kullanıcılar tarafından sayfalarında paylaşılması kullanıcıları o ürünü satın almaya itmektedir. Instangram'daki reklamların kullanıcıların sayfasında paylaşması diğer kullanıcıların bu reklamlara ait ürün ve markalar hakkında daha fazla bilgi edinmesinde az da olsa bir rol oynamaktadır, çünkü bu iki değişken arasındaki ilişkinin değeri 0,414'dür.

\section{Kaynakça}

Aydın, B. (2016). Sosyal Medyada Restoran İmajı: Tripadvisor Örneği, Disiplinlerarası Akademik Turizm Dergisi, 1(1): 13-30.

Bradbury, D. (2011). Data Mining with Linkedln, Computer Fraud\&Security,10: 5-8.

Can, L. (2017). Sosyal Medyada Kulaktan Kulağa İletişime Yönelik İhtiyacin Marka Bağlılığına Etkisi, Insan ve Toplum Bilimleri Araştırmaları Dergisi, 6(1): 140-158.

De Pelsmacker, P., Geuns, M. and Van Den Bergh, J. (2000). Marketing Communications. London: Pearson Education

Distaso, M.W., Mccorkindale, T., Wright, D. K. (2011). How Public Relations Executives Perceive and Measure The Impact of Social Media in Their Organizations. Public Relations Reviews, 37(3): 325-328. 
Djafarova, E. and Rushworth, C. (2016). Exploring The Credibility of Online Celebrities' Instagram Profiles in Influencing The Purchase Decisions of Young Female Users. Computers in Human Behavior, 68: 1-7.

Dunne, A., Lawlor, M.A. and Rowley, J. (2010). Young People's Use of Online Social Networking Sites - A Uses and Gratifications Perspective, Journal of Research in Interactive Marketing, 1(4): P.46-58.

Edin, İ. (2016). Spor Organizasyonlarında Sosyal Dijital Medya Düzenlemeleri ve Sinsi Pazarlama: 2016 Rio Olimpiyatları Örneği, Marmara Üniversitesi Spor Bilimleri Dergisi, 1(2): 55-70.

Ersöz, A.G. (20169. Üniversite Öğrencilerinin Facebook Kullanma Alışkanlıkları: Sosyoloji Bölümü Öğrencileri Örneği, Sosyoloji Konferanslarl, 53 (2016-1): 303-326.

Guesalaga, R. (2016). The Use of Social Media in Sales: Individual and Organizational Antecedents, and The Role of Customer Engagement in Social Media. Industrial Marketing Management, 54: 71-79.

Gürdin, B. (2017). Mobil Reklamlar: Yararlı mı? Tacizkar mı? Organizasyon ve Yönetim Bilimleri Dergisi, 9(2): 1-13.

Gürdin, B. (2017). Sağlık Hizmetleri Sektöründe Reklam Yasağı: Uygulama Örnekleri, Sosyal Ve Beşerî Bilimleri Dergisi, 9(2): 17-30.

Hvass, K. A. and Munar, A. M. (2012). The Take off of Social Media in Tourism. Journal Of Vacation Marketing, 18(2): 93-103.

İnternet: Uğur, E. (2012). Firmalarımızın Sigortası: Marka ve Reklam. Http://Www.İzto.Org.Tr/Portals/0/Iztogenel/Dokumanlar/Firmalarimizin_Sigortasi_Mar ka_ve_Reklam_E_Ugur_26.04.2012\%2023-05-28.Pdf adresinden 2 Şubat 2018'te alınmıştır.

Khan, M.L. (2016). Social Media Engagement: What Motivates User Participation and Consumption on Youtube?. Computers in Human Behavior, 66: 236-247.

Kocabaş, F., Elden, M. ve Çelebi, S. İ. (2000). Marketing P.R. (2. Bask1), Ankara: Mediacat Yayınları.

Kohli C., Suri R. and Kapoor A., (2015) Will Social Media Kill Branding?, Business Horizons, 58: $35-44$

Lavidge, R.J. and G.A. Steiner (1961). A Model for Predictive Measurements of Advertising Effectiveness. Journal of Marketing, 25(October): 59-62.

Odabaşı, Y. ve Oyman, M. (2012). Pazarlama İletişimi Yönetimi (11. Baskı), İstanbul: Mediacat Kitapları.

Onat, F. (2010). "Bir Halkla İlişkiler Uygulama Alanı Olarak Sosyal Medya Kullanımı: Sivil Toplum Örgütleri Üzerine Bir İnceleme”, İletişim Kuram ve Araştırma Dergisi, 31: 103123.

Orzan, G., Burghelea, I., Stupu, L.D. And Boboc, A.L., (2016). The Impact of Social Media Conversation on Brand Image of Cloud Computing Providers. Annals of The University of Oradea, Economic Science Series,1002-1010. 
Özgezmez, Ö. ve Şakar, G.D. (2017). Kruvaziyer İşletmelerin Sosyal Medyadaki Reklamları ile İlgili Tüketici Algılarının İncelenmesine Yönelik Bir Çalışma, Denizcilik Fakültesi Dergisi, Özel Say1: 137-158.

Pickton, D. and Broderick, A. (2001). Integrated Marketing Communications. Harlow: Prentice Hall.

Preeti, M. (2009). Use of Social Networking in a Linguistically and Culturally Rich India, The International Information \& Library Review, 41(3):129-136.

Sabuncuoğlu A. ve Göker, G. (2016). "Sosyal Medyada Görsel Paylaşımdan Reklamcılığa: Instagram Reklamlarının Genç Kullanıcılar Üzerine Etkisine Dair Bir Araştırma", Gümüşhane Üniversitesi Sosyal Bilimler Enstitüsü Elektronik Dergisi, 15( 7):108-131.

Safko, L. (2012). The Social Media Bible. New Jersey: John Wiley And Sons.

Salman, G. ve Eroğlu, E. (2017). Sosyal Medyada Kurum Kimliği Yönetimi: Türkiye’nin En Büyük 500 Şirketi Üzerine Bir Araştırma, E-GIFDER, 5(1): 525-547.

Şengöz, A. ve Eroğlu, E. (2017). Örgütlerde Sosyal Medya Kullanımı: Sosyal Medya Algıları, Amaçları ve Kullanım Alışkanlıkları, E-GIFDER, 5(1): 503-524.

Tezcan, S. (2013). Marka Farkındalığı Yaratmada Televizyon Reklamlarında Ünlü Kullanımının Rolü, Yüksek Lisans Tezi, T.C. İstanbul Ticaret Üniversitesi Sosyal Bilimler Enstitüsü, İstanbul.

Tolon, M. ve Zengin, A.Y. (2016). Bütünleşik Pazarlama Iletişimi Yönetimi. Ankara: Detay Yayıncilık.

Tuten, T. L. (2008). Advertising 2.0: Social Media Marketing in a Web 2.0 World: Social Media Marketing in a Web 2.0 World. Newyork: Greenwood Publishing.

Vinerean, S., Cetina, I., Dumitrescu, L., Tichindelean, M. (2013). The Effects of Social Media Marketing on Online Consumer Behavior. International Journal of Business and Management, 8(14): 66-79.

Weijo, H., Hietanen, J., And Mattila, P. (2014). New Insights into Online Consumption Communities and Netnography. Journal of Business Research, 67: 2072-2078.

Yemez, İ. (2016). Doğrulayıcı Faktör Analizi ile Sosyal Medya Reklamlarına Yönelik Tutum Ölçeğinin Yap1 Geçerliliğinin İncelenmesi: Cumhuriyet Üniversitesi İibf'de Bir Uygulama, C. ̈̈. Iktisadi Ve İdari Bilimler Dergisi, 17(2): 97-118.

Yılmaz, N. (2017). Sosyal Medyada Canlı Yayın Anlayışı, E-Journal of New Media, 1(1): 127136.

Yoldaş, A. ve Ergezer, Ç. (2013). Üniversitede Eğitim Görmekte Olan Öğrencilerin Reklamlara Karşı Tutum ve Davranışları Üzerine Kırgızistan' da Ampirik Bir Araştırma. Niğde Üniversitesi İ̈BF Dergisi 6(1): 280- 297.

Zümrüt, S. (2016). Sosyal Medya Reklamlarının Tüketici Davranışına Etkisi - Instagram Kullanıcıları Üzerine Bir Çalışma, Yüksek Lisans Tezi, T.C. Nuh Naci Yazgan Üniversitesi Sosyal Bilimler Enstitüsü, Kayseri 


\section{EXTENDED ABSTRACT}

\section{A Research on Advertising Applications in The Social Media as A Promotion Tool: Instagram Sample}

The concept of social network is becoming more and more important day by day and becomes an important element of Marketing Communication. Social media is a two-way communication environment where information produced on the internet is shared among users. Today, most people spend their time on social media networks. Social networking websites like Facebook, Twitter, YouTube, Instagram and MySpace have moved communication to a "virtual" environment. The most important feature of social sharing is that the content is created by the user and allows instant sharing. Advertising by AMA is the placement of announcements and persuasive messages in time or space purchased in any of the mass media by business firms, nonprofit organizations, government agencies, and individuals who seek to inform and/or persuade members of a particular target market or audience about their products, services, organizations, or ideas. Social media advertising, which is a type of advertising that is heavily used by businesses, is not questioned by consumers and is ignored even if it is questioned. Instagram is one of the fastest-growing social media tools where online photos are shared, where users share their lives with other users. The Instagram, which was established in 2012 and reported to be more than 400 million users, is expected to reach 2.81 billion dollars. Instagram was also updated on December 15th, 2016 and entered into competition to increase the number of users who were getting more and more intensified. This social network has improved itself by adding the "live" feature after the "Stories" feature. In this paper, we tried to see how attractive the social applications are for the network members. Instagram was selected as a sample social network for research and a survey of the researcher for Instagram users was carried out. The research questions were sent to Instagram users by creating a link. In this study, it was found that $64,7 \%$ of the participants entered Instagram every day, $78,4 \%$ of them were interested in this social network, $45,1 \%$ of them saw the advertisement from Instagram and bought a product, $60,8 \%$ was found to have obtained detailed information about the product in the ad. If some of the remarkable items are briefly mentioned in the averages; the average of "ads in Instagram provides me to notice the brand/product" is 3,80; "ads in Instagram provides me to remember the brand again" is 3,86; "when I meets with the product/brand, I see the advertisement on the Instagram comes to mind" is 4.00. In terms of correlation analysis results, it can be stated that ads belonging to brands are more attractive in Instagram. The strength of the relationship between these two variables is high. When the user's attitude towards ads is positive, the ads in Instagram are more noticeable, users share it on their pages, and they want to know more about the product/brand. The fact that advertisements in Instagram share on the Users page is a little bit more important for other users to learn about these ads' products and brands, because the value of the relationship between these two variables is 0,414 . The results of these findings show that brands' ads are more attractive, that their ads are more memorable, and that sharing the ads on the pages of the users leads the users to buy that product. 